\title{
Non-communicable diseases among children in Ghana: health and social concerns of parent/caregivers.
}

\author{
Alfred E Yawson ${ }^{1}$, Aaron A Abuosi², Delali M Badasu ${ }^{3}$, Deborah Atobra ${ }^{4}$, \\ Francis A Adzei ${ }^{2}$, John K. Anarfi
}

1. Department of Community Health, School of Public Health, College of Health Sciences, University of Ghana, Korle-Bu, Accra, Ghana.

2. Department of Public Administration and Health Services Management, University of Ghana Business School, Ghana.

3. Regional Institute for Population Studies, University of Ghana, Ghana.

4. Institute of African Studies, University of Ghana, Ghana.

\begin{abstract}
Background: Globally, there is a progressive rise in the burden of non-communicable diseases (NCDs). This paper examined the health and social concerns of parents/caregivers on in-patient care for children with NCDs in Ghana.

Methods: This was a cross-sectional study in three large health facilities in Ghana (the largest in the South, the largest in the North and the largest in the Eastern part of Ghana. Data was collected with a structured questionnaire among 225 caregivers ( $\geq 18$ years) of 149 children with NCDs in health facilities in the three regions. Data was analyzed with simple descriptive statistics.

Results: Most caregivers 169(75.0\%) were women, relatively young (median age 35years), mostly married and resided in urban areas. Sickle cell disease was the commonest NCD among the children. All 169(75.0\%) caregivers believed children suffer NCDs because of sins of parents/ancestors, 29(12.9\%) believed herbalists/spiritualists have insights into treating NCDs and 73(32.6\%) have previously used herbs/traditional medicine for child's illness. NCD in children was a burden and caused financial difficulties for families. Most caregivers ( $>96.0 \%$ ) indicated NCDs in children should be included in national health insurance benefits package and a comprehensive national NCD policy is needed.

Conclusion: Absence of national NCD policy for children is a major challenge. The burden of care rests mainly on the parents/ caregivers. A national strategic intervention on the importance of awareness generation on the causes, risk factors, prevention and treatment of NCDs for families and communities is essential. Government support through national health and social policy initiatives are essential.
\end{abstract}

Keywords: Non-communicable diseases, children, caregivers, health policy, social policy, Ghana.

DOI: http://dx.doi.org/10.4314/ahs.v16i2.6

Cite as: Yawson AE, Abuosi AA, Badasu DM, Atobra D, Adzei FA, Anarfi JK. Non-communicable diseases among children in Ghana: health and social concerns of parent/ caregivers. Afri Health Sci 2016;16(2): 378-388. http:// dx.doi.org/10.4314/abs.v16i2.6

\author{
Corresponding author: \\ Alfred E Yawson, \\ Department of Community Health, \\ University of Ghana Medical School, \\ College of Health Sciences, Room 46, \\ P. O. Box 4236, Korle-Bu, Accra, Ghana. \\ OR filfiyawson@hotmail.com \\ Telephone: +233 302 681648; \\ Cell phone: +233244662711 , \\ +233206301049 \\ Email Address: aeyawson@yahoo.com \\ OR fiifiyawson@hotmail.com
}

\section{Background}

Globally, there is a progressive rise in the burden of noncommunicable diseases (NCDs) attributable to factors including high risk lifestyles of populations associated with modernization, changes in nutrition, and less activity among children ${ }^{1-4}$. There is an increasing burden of NCDs in developing countries, among the lower socioeconomic population groups and the less-educated ${ }^{5,6}$, and this warrants that NCDs need policy attention.

Developing countries continue to bear a high burden of morbidity and mortality from infectious disease while non-communicable diseases are increasing in prevalence ${ }^{1,3}$. In Ghana, global disease burden estimates by the 
World Health Organization indicates NCDs and injuries account for $46 \%$ of the causes of morbidity and $40 \%$ of the causes of mortality ${ }^{7}$.

NCDs have been observed among children in the developing countries. In Ghana, childhood cancers have been on the increase ${ }^{8}$ and autopsy findings on mortalities in adolescents from the Korle-Bu Teaching Hospital (the largest tertiary care health facility in Ghana) showed NCDs contribute $41 \%$ of the deaths among adolescents 9 The burden of non-communicable diseases in children in Ghana could be described as a neglected epidemic which poses a challenge to health and social development ${ }^{10}$.

Unfortunately, though the population of Ghana, like most other developing countries is predominantly young ${ }^{11}$, there has not been any clear health and social policy towards the control of NCDs among the younger population. Generally, public health policy on NCDs has not received priority attention in health planning in Ghana, until a few years ago ${ }^{12}$. Also, the health care policy in Ghana prior to 2005, placed little emphasis on the control and prevention of NCDs (for example diabetes), probably due to the notion that these NCDs were $\operatorname{rare}^{13,14}$.

Ministry of Health has a child health policy for children under five years from 2007-2015, ${ }^{15}$ as well as the Ministry of Health's National Policy for the Prevention and Control of Chronic Non-Communicable Diseases in Ghana ${ }^{16}$. These policies however, do not highlight chronic disease in children as a burden which deserves national attention. The government of Ghana, through the Ministry of Employment and Social Welfare has a policy on the aged that emphasizes comprehensive care for the older adults including $\mathrm{NCDs}^{17}$. There is however, no corresponding policy for NCDs in children. The Ministry of Health, unveiled a policy document 'Creating Wealth Through Health' in 2005 as a health paradigm shift emphasizing health promotion and prevention of disease to garner a healthy national population ${ }^{18}$. The policy concept emphasizing regenerative health and nutrition ${ }^{19}$, has not focused on children, despite the increasing prevalence of NCDs especially among adolescents.
Families of children with NCDs may experience severe financial and social cost to the care of these children. A recent publication in Ghana demonstrated that the national health insurance provides significant financial relief to parents/caregivers in the care of their children with NCDs. However, parents/caregivers still face considerable financial burden of caring for their children with NCDs during hospitalization ${ }^{20}$. The financial and social burden of most parents/caregivers are exacerbated by these out-of-pocket payments. In addition, financial support from relatives and friends for the health care of children with NCDs have been shown to be minimal ${ }^{20}$. The absence of comprehensive coverage for NCDs in the general population and especially among children (e.g childhood cancers) by the national health insurance scheme in Ghana ${ }^{21}$ imposes huge financial burden on families in accessing health care for their chronically sick children.

The objectives of this study were to examine the health and social concerns of parents/caregivers on the care of children with NCDs in Ghana, and suggest suitable policy measures for preventing NCDs in the children.

\section{Methods}

This was a cross-sectional study that collected quantitative data from caregivers ( $\geq 18$ years) of children with NCDs in three large health facilities in the South, North and Eastern parts of Ghana. Field work for the entire research was conducted over a three-week period in January, 2013.

\section{Site of study}

The study was conducted in the three major national hospitals; Korle-Bu Teaching Hospital, KBTH (the largest tertiary hospital in Ghana, located in the Greater Accra region, in the south), the Komfo Anokye Teaching Hospital, KATH (the largest hospital in the middle and northern parts of Ghana, located in the Ashanti region) and the Volta Regional Hospital, VRH (the largest hospital in the Eastern parts of Ghana, located in the Volta region). These foremost referral centres receive cases of NCDs from all over the country and were purposively selected to reflect the health and social factors relating to care. 


\section{Sampling methods}

Health facility interviews were conducted in these large health centres. A total enumeration of all parent/care givers of children on admission during the study period in the Child Health Department and Sickle Cell Disease Unit of the hospitals were used. The field team in each hospital consisted of two supervisors and 24 interviewers.

\section{Study population}

The population for the survey were parents/caregivers $(\geq$ 18 years) of children on admission with NCDs, in units or departments of the three large hospitals during the survey period and those who consented to be part of the study were recruited. For this analysis, children were defined as persons less than 18 years of age and primary care givers were persons responsible for the direct care (bathing, feeding, and administering medication) of the child with NCD. Overall, 225 care givers (of 149 children with NCDs) on admission in the three hospitals were interviewed.

\section{Data collection}

An interviewer administered structured questionnaire was used for data collection. Data was collected on socio-demographic characteristics of caregivers. Views of parent/ care givers views on health and social domains regarding NCDs in children were assessed. In this analysis four themes (each with sub-themes) were assessed; Health beliefs, effect on child and family, constraints in access to care and type of health care. The sub-themes generally assessed knowledge, beliefs, care giving experiences, and health seeking behaviours of families of children with NCDs. Data was also collected on concerns of care givers on government support and social/ health policy on NCD among children. The three main themes for this assessment were; constraints to government support for health and social policy, Need of a national NCD policy for children and improving NCD care in children

\section{Data analysis}

Descriptive statistics such as frequencies, proportions and ratios were used for outcome variables selected for analysis. Summary statistics including mean and median were used for measured variables. All quantitative data was analyzed with Statistical Package for the Social Sciences (SPSS) version ${ }^{21}$.

\section{Ethical issues}

Ethical approval was obtained from the Institutional Review Board of Noguchi Memorial Institute for Medical Research (NMIMR), College of Health Sciences, University of Ghana (Federal Wide Assurance FWA 00001874, IRB 00001276, NMIMR-IRB CPN 014/12-13, IORG 0000908 ). Written informed consent was obtained from all the participants in the study.

\section{Results}

A total of 225 parents/ caregivers of children with NCDs were involved, 97 (43.1\%) from KBTH, 94 (41.8\%) from KATH and 34 (15.1\%) from VRH. Among parents/caregivers $169(75.1 \%)$ were females (female: male sex ratio of 3:1), age ranged from 18-68 years and median age was 35 years. As demonstrated in Table 1, most parents/caregivers were urban residents $184(81.9 \%)$ with some formal education. Most parents/caregivers were Christians, 195 (86.5\%), most were currently married, 140 (63.1\%) and belonged to the Akan ethnic group, 125 (55.6\%). The commonest reported occupation was trading or as businessmen/women, 72 (32.0\%). Over three quarters of primary caregivers were parents of these children 169 $(75.1 \%)$. 
Table 1: Socio-demographic characteristics of parent/caregivers ( $\geq 18$ years) of children on admission

with NCDs in the three large Hospitals in Ghana.

\begin{tabular}{|c|c|c|}
\hline Characteristics & Frequency & Percentage \\
\hline $\begin{array}{l}\text { Place of residence } \\
\text { Urban } \\
\text { Peri Urban } \\
\text { Rural } \\
\text { Total }\end{array}$ & $\begin{array}{c}184 \\
20 \\
21 \\
225\end{array}$ & $\begin{array}{c}81.9 \\
8.8 \\
9.3 \\
100.0\end{array}$ \\
\hline $\begin{array}{l}\text { Educational level } \\
\text { No education } \\
\text { Primary } \\
\text { Middl/JSS/JHS } \\
\text { Sec/SHS/Vocational Technical } \\
\text { Post-secondary/Polytechnic } \\
\text { University } \\
\text { Total } \\
\end{array}$ & $\begin{array}{l}17 \\
27 \\
69 \\
42 \\
30 \\
41 \\
225 \\
\end{array}$ & $\begin{array}{c}7.7 \\
11.8 \\
30.5 \\
18.6 \\
13.2 \\
18.2 \\
100.0 \\
\end{array}$ \\
\hline $\begin{array}{l}\text { Religion } \\
\text { Charismatic/Pentecostal } \\
\text { Protestant (Anglican } \\
\text { Methodist/Presbyterian/Baptist/Lutheran) } \\
\text { Catholic } \\
\text { Moslem } \\
\text { Traditional/spiritualist } \\
\text { Total }\end{array}$ & $\begin{array}{c}93 \\
82 \\
20 \\
27 \\
3 \\
225 \\
\end{array}$ & $\begin{array}{c}41.3 \\
\\
36.5 \\
8.7 \\
12.0 \\
1.4 \\
100.0 \\
\end{array}$ \\
\hline $\begin{array}{l}\text { Ethnicity } \\
\text { Akan } \\
\text { Ewe } \\
\text { Ga-dangme } \\
\text { Mole-dagbani } \\
\text { Other Ghanaian } \\
\text { Total } \\
\end{array}$ & $\begin{array}{l}125 \\
40 \\
21 \\
17 \\
22 \\
225\end{array}$ & $\begin{array}{c}55.6 \\
17.8 \\
9.3 \\
7.6 \\
9.8 \\
100.0 \\
\end{array}$ \\
\hline $\begin{array}{l}\text { Marital status } \\
\text { Currently married } \\
\text { Never Married } \\
\text { Widowed } \\
\text { Living together } \\
\text { Separated } \\
\text { Divorced } \\
\text { Total } \\
\end{array}$ & $\begin{array}{c}140 \\
57 \\
12 \\
7 \\
4 \\
4 \\
224 \\
\end{array}$ & $\begin{array}{c}63.1 \\
25.7 \\
5.4 \\
3.2 \\
1.4 \\
1.4 \\
100.0 \\
\end{array}$ \\
\hline $\begin{array}{l}\text { Profession } \\
\text { Trader, Businessman/woman } \\
\text { Professional/Technical } \\
\text { Artisan } \\
\text { Administrative/managerial } \\
\text { Agricultural animal husbandry/fishing/hunting } \\
\text { Homemaker } \\
\text { Other } \\
\text { Total }\end{array}$ & $\begin{array}{c}72 \\
56 \\
32 \\
13 \\
12 \\
2 \\
38 \\
225\end{array}$ & $\begin{array}{c}32.0 \\
24.7 \\
14.2 \\
5.9 \\
5.5 \\
0.9 \\
17.0 \\
100.0\end{array}$ \\
\hline $\begin{array}{l}\text { Relationship of caregiver to child with NCD } \\
\text { Parent } \\
\text { Self(respondent) } \\
\text { Other relative } \\
\text { Other non relative } \\
\text { Total } \\
\end{array}$ & $\begin{array}{c}169 \\
26 \\
24 \\
6 \\
225\end{array}$ & $\begin{array}{c}75.1 \\
11.6 \\
10.6 \\
2.6 \\
100.0\end{array}$ \\
\hline $\begin{array}{l}\text { Type of care being provided to child with NCD } \\
\text { Primary } \\
\text { Secondary } \\
\text { Total } \\
\end{array}$ & $\begin{array}{c}196 \\
29 \\
225\end{array}$ & $\begin{array}{c}87.1 \\
12.9 \\
100.0\end{array}$ \\
\hline
\end{tabular}

Table 2 shows the basic characteristics of the 149 children with NCDs on admission during the three week survey period. Over half of these children were males ,91(61.1\%). Among all the children, most were less than 5 years of age, $61(40.9 \%)$. The commonest NCD reported in the children was sickle cell disease, $39(26.2 \%)$, followed by congenital deformity, $26(17.4 \%)$. Other NCDs reported included; asthma, respiratory tract disease, hypertension and certain chronic conditions that could not be readily characterized (i.e. diagnoses were not confirmed during period of data collection). Considering age characteristics of these children, Sickle cell disease was more common in children $\geq 5$ years, diabetes in those $\geq 10$ years and congenital deformity in those $<5$ years. 
Table 2: Age and sex characteristics of children on admission and types of NCDs reported to the three large Hospitals in Ghana.

\begin{tabular}{|c|c|c|c|c|}
\hline \multirow[b]{2}{*}{ Characteristics } & \multicolumn{4}{|l|}{ Age group } \\
\hline & $\begin{array}{l}\text { Under } 5 \text { years } \\
(\%)\end{array}$ & 5-9 years $(\%)$ & $\begin{array}{l}10 \text { years and } \\
\text { above }(\%)\end{array}$ & Total (\%) \\
\hline \multicolumn{5}{|l|}{ Sex } \\
\hline Male & $38(62.3)$ & $24(58.5)$ & $29(61.7)$ & $91(61.1)$ \\
\hline Female & $23(37.7)$ & $17(41.5)$ & $18(38.3)$ & $58(38.9)$ \\
\hline Total & $61(100)$ & $41(100)$ & $47(100)$ & $149(100)$ \\
\hline \multicolumn{5}{|c|}{ Non communicable disease } \\
\hline Cancer & $4(7.0)$ & $2(5.0)$ & $6(11.5)$ & $12(8.1)$ \\
\hline Diabetes & $4(7.0)$ & $4(10.0)$ & $16(30.8)$ & $24(16.1)$ \\
\hline Sickle Cell Disease & $11(19.3)$ & $16(40.0)$ & $12(23.1)$ & $39(26.2)$ \\
\hline Congenital Deformity & $13(22.8)$ & $4(10.0)$ & $9(17.3)$ & $26(17.4)$ \\
\hline Others & $25(43.9)$ & $14(35.0)$ & $9(17.3)$ & $48(32.2)$ \\
\hline Total & $57(100)$ & $40(100)$ & $52(100)$ & $149(100)$ \\
\hline
\end{tabular}

Views of parent/ care givers regarding care for NCDs in children

Regarding health beliefs, almost half of parents/caregivers agreed it is not normal for children to suffer chronic diseases, 99 (44.1\%). Majority of parents/caregivers 169, (75.0\%) agreed children suffer NCDs because of sins of parents or their ancestors as shown in Table 3. Regarding effect on child and family, most parents/caregivers agreed NCDs had negatively affected child's physical growth and school attendance and agreed that caring for the sick child was a burden. In addition, the care for the child had caused them to spend so much money and cre- ated financial difficulties for the family. Constraints to access to care were amply demonstrated in parents/caregivers agreeing that they have financial difficulties paying for child's medical care and make regular visits to the health care facility.

Interestingly, almost all parents/caregivers 219 (97.4\%), agreed to be using regular medical checks in hospital/ clinic for child's illness, yet $73(32.6 \%)$ of caregivers agreed to have previously used herbs/traditional medicine for the child's illness. Not surprisingly, 29 (12.9\%) of parents/caregivers believed Herbalists/ Spiritualist have insights into care of NCDs in children. 
Table 3: Views of Parent/ care givers views on health and social domains regarding inpatient care for NCDs in children in three large hospitals in Ghana.

\begin{tabular}{|c|c|c|c|c|c|c|c|c|c|c|}
\hline \multirow[b]{2}{*}{$\begin{array}{l}\text { Parent/ } \\
\text { care } \\
\text { givers } \\
\text { views }\end{array}$} & \multicolumn{2}{|c|}{ Health Beliefs } & \multicolumn{4}{|c|}{ Effect on child and family } & \multicolumn{2}{|c|}{$\begin{array}{l}\text { Constraints in access to } \\
\text { care }\end{array}$} & \multicolumn{2}{|c|}{ Type of health care } \\
\hline & $\begin{array}{l}\text { Not } \\
\text { normal for } \\
\text { children to } \\
\text { suffer } \\
\text { chronic } \\
\text { diseases } \\
(\%)\end{array}$ & $\begin{array}{l}\text { Children } \\
\text { suffer } \\
\text { NCD } \\
\text { because } \\
\text { of sins of } \\
\text { parents/ } \\
\text { ancestors } \\
(\%)\end{array}$ & $\begin{array}{l}\text { Illness } \\
\text { negatively } \\
\text { affected } \\
\text { child's } \\
\text { physical } \\
\text { growth } \\
(\%)\end{array}$ & $\begin{array}{c}\text { Illness } \\
\text { negatively } \\
\text { affected } \\
\text { child's } \\
\text { school } \\
\text { attendance } \\
(\%)\end{array}$ & $\begin{array}{c}\text { Parents/ } \\
\text { caregivers } \\
\text { felt child } \\
\text { was a } \\
\text { burden }(\%)\end{array}$ & $\begin{array}{l}\text { Child's illness } \\
\text { caused } \\
\text { parents/caregiver } \\
\text { to spend so } \\
\text { much money } \\
(\%)\end{array}$ & $\begin{array}{c}\text { Parents/ } \\
\text { caregivers } \\
\text { have financial } \\
\text { difficulties } \\
\text { paying for } \\
\text { child's medical } \\
\text { care }(\%)\end{array}$ & $\begin{array}{c}\text { Parents/ } \\
\text { caregivers } \\
\text { used regular } \\
\text { medical } \\
\text { checks in } \\
\text { hospital/clinic } \\
\text { for child's } \\
\text { illness }(\%)\end{array}$ & $\begin{array}{c}\text { Herbalists/ } \\
\text { Spiritualist } \\
\text { have } \\
\text { insights } \\
\text { into NCDs } \\
\text { in children } \\
(\%)\end{array}$ & $\begin{array}{c}\text { Parents/ } \\
\text { caregivers used } \\
\text { herbs/traditional } \\
\text { medicine for } \\
\text { child's illness } \\
(\%)\end{array}$ \\
\hline Disagreed & $113(50.0)$ & $24(10.7)$ & $97(43.3)$ & $92(41.1)$ & $143(63.7)$ & $52(23.0)$ & $117(52.0)$ & $5(2.1)$ & $181(80.6)$ & $117(52.2)$ \\
\hline Uncertain & $13(5.9)$ & $3214.4)$ & $20(8.9)$ & $26(11.4)$ & $10(4.5)$ & $6(2.8)$ & $23(10.1)$ & $1(0.5)$ & $15(6.5)$ & $34(15.2)$ \\
\hline Agreed & $99(44.1)$ & $169(75.0)$ & $108(47.8)$ & $107(47.4)$ & $72(31.8)$ & $167(74)$ & $86(38)$ & $219(97.4)$ & $29(12.9)$ & $73(32.6)$ \\
\hline Total (n) & 225 & 225 & 225 & 225 & 225 & 225 & 225 & 225 & 225 & 225 \\
\hline
\end{tabular}

As demonstrated in Table 4, constraints to government support for health and social policy from parents/caregivers indicated $91(40.6 \%)$ of parent/caregivers agreed NCDs were diseases of adults and that the media may not be interested in discussing it. In addition, a third of parent/caregivers believed threat of communicable diseases was so serious they were more likely to be the priority of policy makers, while $82(36.5 \%)$ indicated there was limited political will for NCDs in children.

Over half of caregivers were uncertain whether existing health policies were being implemented and yet almost all caregivers 219 (97.5\%) agreed Ghana needed a comprehensive policy on NCDs. An overwhelming majority of parent/caregivers indicated that improving care for NCDs in children should include the need to develop a policy for periodic screening for NCDs among children at risk as well as include treatment and prevention of NCDs in the curricula of health training institutions. Another important view of caregivers was that cost of care for NCDs in children should be included in the national health insurance benefit package. 
Table 4 : Parents/ caregivers views on government support, health and social policy concerns on NCDs in children in Ghana

\begin{tabular}{|c|c|c|c|c|c|c|c|c|c|c|c|c|}
\hline & Constrain & s to Gover & ment support f & o health a & nd social po & & $\begin{array}{l}\text { Need for } \mathrm{n} \\
\text { policy for } \mathrm{c}\end{array}$ & $\begin{array}{l}\text { national NCD } \\
\text { children }\end{array}$ & & proving NCD & care in chil & dren \\
\hline & $\begin{array}{l}\text { NCDs } \\
\text { are } \\
\text { diseases } \\
\text { of adults } \\
(\%) \\
\end{array}$ & $\begin{array}{c}\text { Media } \\
\text { not } \\
\text { interested } \\
\text { in public } \\
\text { policy on } \\
\text { NCDs } \\
(\%) \\
\end{array}$ & $\begin{array}{c}\text { Threat of } \\
\text { communicable } \\
\text { diseases so } \\
\text { serious, } \\
\text { priority of } \\
\text { policy makers } \\
(\%) \\
\end{array}$ & $\begin{array}{c}\text { Lack of } \\
\text { political } \\
\text { will by } \\
\text { policy } \\
\text { makers } \\
(\%) \\
\end{array}$ & $\begin{array}{l}\text { No } \\
\text { donor } \\
\text { support } \\
\text { for } \\
\text { NCDs } \\
\text { in } \\
\text { children } \\
(\%) \\
\end{array}$ & $\begin{array}{c}\text { Existing } \\
\text { health } \\
\text { policies not } \\
\text { being } \\
\text { implemented } \\
(\%) \\
\end{array}$ & \begin{tabular}{|c} 
Health \\
policy \\
on \\
NCDs \\
in \\
children \\
not \\
needed \\
$(\%)$ \\
\end{tabular} & $\begin{array}{c}\text { Ghana needs a } \\
\text { comprehensive } \\
\text { policy on } \\
\text { NCDs }(\%) \\
\end{array}$ & \begin{tabular}{|c} 
Need to \\
include NCDs \\
in school \\
curricula $(\%)$ \\
\end{tabular} & $\begin{array}{c}\text { Emphasize } \\
\text { regenerative } \\
\text { health in } \\
\text { health } \\
\text { institutions } \\
(\%) \\
\end{array}$ & $\begin{array}{c}\text { Include } \\
\text { NCDs in } \\
\text { health } \\
\text { insurance } \\
\text { benefit } \\
\text { package } \\
(\%) \\
\end{array}$ & $\begin{array}{l}\text { Develop policy } \\
\text { for periodic } \\
\text { screening for } \\
\text { NCDs }\end{array}$ \\
\hline Disagreed & $108(48.0)$ & $165(73.5)$ & $110(48.8)$ & $93(41.2)$ & $45(19.9)$ & $34(15.1)$ & $167(74.1)$ & $3(1.5)$ & $6(2.5)$ & $2(1.0)$ & $6(2.5)$ & $3(1.5)$ \\
\hline Uncertain & $26(11.4)$ & $42(18.8)$ & $43(19.2)$ & $50(22.4)$ & $49(21.6)$ & $127(56.6)$ & $35(15.9)$ & $2(1.0)$ & $3(1.5)$ & $1(0.5)$ & $2(1.0)$ & $2(1.0)$ \\
\hline Agreed & $91(40.6)$ & $18(7.9)$ & $72(32.0)$ & $82(36.5)$ & $131(58.5)$ & $64(28.3)$ & $23(10.0)$ & $220(97.5)$ & $216(95.9)$ & $222(98.5)$ & $217(96.4)$ & $220(97.5)$ \\
\hline Total (n) & 225 & 225 & 225 & 225 & 225 & 225 & 225 & 225 & 225 & 225 & 225 & 225 \\
\hline
\end{tabular}

\section{Discussion}

The demographic characteristics of caregivers indicated burden of care giving was borne mainly by women, who were mostly mothers of the children. This finding is in agreement with a national survey of caregiving among the aged ( $\geq 50$ years) in Ghana which indicated that the burden of caregiving rest heavily on women ${ }^{22}$.

In addition, the caregivers were mainly young married women involved in trading, who probably have other children to care for as they worked to support their family. The opportunity cost of taking caregivers away from their trading and work activities to care for the sick child in health facilities have implications for the wellbeing of other members of the family ${ }^{23}$. The cost of health care, cost of transportation and daily living cost, as well as the opportunity cost to caregivers increases the economic and social burden on the household and family $y^{20,23}$.
Although most of the children identified with NCDs in these large hospitals were less than 5 years of age, others were of school going age. This implies time out of school and time away from other social developmental activities; academic progression of the sick children may be negatively affected.

It was not surprising that sickle cell disease was the most common NCD in this hospital -based population. Sickle cell disease has long been identified to afflict children in Ghana and has severe educational and developmental challenges as well as economic and social challenges for the family ${ }^{20,24}$. The analysis showed most caregivers believed NCDs had negatively affected child's physical growth and school attendance and had caused caregivers / parents to spend so much money. This finding conforms to earlier research on the social and economic burden of NCDs on families in Ghana ${ }^{20,24}$. 
Diabetes, especially, type 2 diabetes in the young, is also an increasing problem with potentially serious outcomes ${ }^{25}$.The increasing prevalence of pediatric type 2 diabetes coincides with increasing obesity in children ${ }^{26}$. This needs to be urgently addressed, given the potential threat of a rapid increase in childhood type 2 diabetes ${ }^{27}$.

Although in this health facility-based survey elevated BP was not identified as a common NCD among the children, elevated blood pressure has been found among Ghanaian children ${ }^{28}$. It has been shown that not only is high BP detectable in children and adolescents, it is increasing in prevalence with potentially severe consequences ${ }^{26,29,30}$. Without intervention, high BP in childhood will eventually increase the risk of premature cardiovascular (CV) disease. Prevention and management of obesity, hypertension, diabetes and other NCDs, are critical for ensuring the health of children and young people. Thus, lifestyle modifications, better nutritional choices, and increased physical activity, are obvious first-line approaches to the management of such risk factors ${ }^{31,32}$.

To improve these first-line approaches to management of risk factors of NCDs in children, financial accessibility to health care is an important public policy option. There is an increasing burden of NCDs in developing countries, among the lower socio-economic population groups and the less-educated ${ }^{5,6}$. Unfortunately communicable diseases are still prevalent in these population groups and governments in developing and low middle income countries are faced with the challenge of continuing to spend limited resources on common endemic conditions (such as malaria, respiratory tract infections and diarrhoeal disease among children).

National efforts are actively needed to improve the care of children with NCDs. Interestingly, majority of the children with NCDs in this survey had been insured under the national health insurance scheme (NHIS), and almost all parents/caregivers were of the view that NCDs in children should be included in the NHIS benefit package. It is important that the NHIS in Ghana includes care and treatment of NCDs, especially childhood cancers under the scheme; a definite national health and social policy in this direction is critical.
Apart from the financial burden limiting access to care by children with NCDs, certain social and cultural factors such as knowledge, beliefs and attitudes of parents/caregivers influence health seeking behaviours and medical management of the children ${ }^{33-35}$. Our assessment showed that, parents/caregivers believed NCDs were diseases of adults and it was not normal for children to suffer chronic diseases. If they did, it was because of sins of parents or their ancestors.

NCDs are perceived as afflictions by supernatural powers in traditional Ghanaian societies and by the traditional and faith-healing health systems ${ }^{33-35}$. For these reasons some cases of NCDs may not be taken to health facilities or may be taken there at advanced stages; children are thus victims of health-seeking behaviours of parents / caregivers. This view was confirmed in this analysis, a third of caregivers had previously used herbs or traditional medicine for managing the child's illness. A national health education and promotion initiative for early risk detection and management of NCDs is essential if the health of Ghanaian children with NCDs are to improve.

Governmental support, social and health policies and preventive programmes on NCDs will be critical to complement the efforts by caregivers. Caregivers were however, uncertain as to how existing health policies were being implemented and believed Ghana needed a comprehensive policy on NCDs as well as inclusion of treatment and prevention of NCDs among children in the curricula of health training institutions.

\section{Limitations}

Some questions asked were sensitive issues regarding traditional medicine or religious beliefs, and information bias was most likely, considering that the survey was conducted within the hospital setting. The sample used for this study were only those who had accessed health care, and this would question the validity of the population level inferences from this study findings. In low middle income settings, wealthier and more educated individuals tend to have relatively better access to health care as well as greater knowledge about disease conditions, compared with those in lower socioeconomic status (SES) groups 36,37. It is likely there are many children with NCDs whose parents/ caregivers may not be aware of their disease 
conditions, or may not be able to access healthcare because of unaffordability. In addition, those who have been accessing care may be severely chronic ill children and this may affect the responses of the caregivers.

\section{Conclusion and recommendations}

NCDs in children are real and do exist in health facilities in Ghana. Caregivers/ parents face enormous social, economic and financial challenges in caring for the children. The absence of a comprehensive national NCD policy for children is a major challenge.

Early risk detection and management of NCDs in children should be a national goal. Strengthening the health systems should be the primary focus, yet a nationwide chronic care initiative will need to build robust partnerships with community-based institutions for health prevention and promotion. These initiatives could range from schools as sites of health promotion, to the community and local government, to vigorous engagement with local media; women's groups, and faith-based groups 38 .

A national strategic intervention on the importance of awareness generation on the causes, risk factors, prevention and treatment of NCDs for families and communities is essential. It is clear that most NCD and their biological risk factors are modifiable, so awareness generation for promoting the consumption of healthy food and discouraging unhealthy foods, better physical activity and improved living conditions can prevent the NCDs.

A comprehensive health and social policy on NCDs in children should be national policy target. Pre-service and in-service training for health workers on NCDs among children is important to garner early risk detection and management.

\section{Acknowledgement}

We are grateful to all respondents and interviewers who made the survey in Ghana possible. Financial support was provided by the University of Ghana Office of Research Innovation and Development (ORID). The University of Ghana's Regional Institute of Population Studies (RIPS) provided training facilities, data entry support, and storage of materials.

\section{Competing interest}

The authors declare no conflict of interest. The views expressed in this paper are those of the authors. No official endorsement by the Ministry of Health of Ghana/ Ghana Health Service is intended or should be inferred.

\section{Author contribution}

Alfred E Yawson, Aaron A Abuosi, Delali M Badasu developed the concept. Alfred E Yawson, Aaron A Abuosi, Delali M Badasu, Deborah Atobra, Francis A Adzei, and John Anarfi were principal investigators of the multidisciplinary team that conducted the survey. Alfred $\mathrm{E}$ Yawson, Aaron A Abuosi, and Francis A Adzei contributed to the writing and reviewing of the various sections of the manuscript. All the authors reviewed the final version of the manuscript before submission.

\section{References}

1. Amuna P and Zotor FB . Epidemiological and nutrition transition in developing countries: impact on human health and development. Proceedings of the Nutrition Society, 2008;67(1):84-97.

2. Daar AS, Singer PA, Persad DL, Pramming SK, Matthews DR, Beaglehole R. Grand challenges in chronic non-communicable diseases. Nature, 2007;450:494-496.

3. Amoah AG, Kengne AP, Mbanya JCC. Cardiovascular complications of diabetes mellitus in sub-Saharan Africa. Circulation, 2005; 6(112):3592-601

4. Biritwum RB, Gyapong J, MensahG. The Epidemiology of Obesity in Ghana. Ghana Med Journal. 2005;39(3): 82-85.

5. Wu F, Guo Y, Chatterji S, Zheng Y, Naidoo N, Jiang Y, Biritwum R, Yawson A, Minicuci N, Rodriguez A, Espinoza B, Maximova T, Peltzer K, Phaswanamafuya $\mathrm{N}$, Snodgrass JJ, Thiele E, Ng N and Kowal P. Common risk factors for chronic non-communicable diseases among older adults in China, Ghana, Mexico, India, Russia and South Africa: the study on global AGEing and adult health (SAGE) wave 1. BMC Public Health 2015, 15:88 doi:10.1186/s12889-

6. Kowal P , Biritwum RB, Mensah G, Minicuci N, Yawson AE. Ghana: Study on global AGEing and adult health (SAGE) Wave 1 National Report, 2014. Report on SAGE survey in Ghana (Wave I, 2007-2008) by the World Health Organization in collaboration with the Depart- 
ment of Community Health, University of Ghana Medical School, College of Health Sciences, Korle-Bu.

7. Horton R. The Global Burden of Disease Study 2010 (GBD 2010). The Lancet. 2012; 380 (9859): 2053-2054.

8. Badasu D. Epidemiological transition, the burden of non-communicable diseases and tertiary health policy for child health in Ghana: lessons from a study on children in a Ghanaian Teaching Hospital. 2007. Paper submitted to the 2007 UAPS conference.

9. Ohene SA, Tettey Y, Kumoji R. Cause of death among Ghanaian adolescents in Accra using autopsy data. BMC Research Notes, 2011;4:353. http://www.biomedcentral. com/1756-0500/4/353. doi:10.1186/1756-0500-4-353

10. Aikins A-G. Ghana's neglected chronic disease epidemic: a developmental challenge. Ghana Med J. 2007;41(4):154-159.

11. Unwin N, Alberti KG. Chronic non-communicable diseases. Ann Trop Med Parasitol, 2006;100(5-6):455-464. doi: 10.1179/136485906X97453

12. Ministry of Health Ghana . Annual Report, 2007. Published by the Ministry of Health, Republic of Ghana, Accra, 2008

13. Dodu SR. The incidence of diabetes mellitus in Accra (Ghana); a study of 4,000 patients. West African Med J, 1958;7(3):129-34.

14. Amoah AGB, Owusu SK, Acheampong JW, Agyenim-Boateng K, Asare HR, Owusu AA, Mensah-Poku MF, Adamu FC, Amegashie RA, Saunders JT, Fang WL, Pastors JG, Sanborn C, Barrett EJ, and Woode MK. A national diabetes care and education programme: the Ghana model. Diabetes Research and Clinical Practice, 2000; 49(2-3):149-57.

15. Ministry of Health: Under Five's Child Health Policy: 2007-2015. In. Accra, Ghana; 2008.

16. Ministry of Health: National Policy for the Prevention and Control of Chronic Non-Communicable Diseases in Ghana. In. Accra, Ghana; 2011.

17. Ghana National Ageing Policy . Ministry of Employment and Social Welfare of Ghana 'Ageing with Security and Dignity'. Published by Ministry of Employment and Social Welfare, Accra, Ghana, 2010

18. Ministry of Health Ghana . Annual Report, 2005. Published by the Ministry of Health, Republic of Ghana, Accra, 2006

19. Tagoe HA and Dake FAA. Healthy lifestyle behaviour among Ghanaian adults in the phase of a health policy change. Globalization and Health, 2011;7:7. doi:10.1186/1744-8603-7-7http://www.globalizationandhealth.com/content $/ 7 / 1 / 7$

20. Abuosi AA, Adzei FA, Anarfi JK, Badasu DM, Atobrah D and Yawson AE. Investigating parents/caregivers financial burden of care for children with non-communicable diseases in Ghana. BMC Pediatrics 2015, 15:185 doi:10.1186/s12887-015-0504-7. http://www.biomedcentral.com/1471-2431/15/185

21. NationalHealth Insurance ACT of Ghana. National Health Insurance ACT 650 of the Parliament of the Republic of Ghana, August, 2003. Published by Ghana Assembly Press, Accra, Ghana, 2003.

22. University of Ghana, Department of Community Health. Ghana National Report on World Health Organization's Study on global AGEing and adult health (SAGE) in Ghana, Wave 1. Geneva:WHO. 2014.

23. Abegunde DO, Mathers CD, Adam T, Ortegon M, Strong K. The burden and costs of chronic diseases in low-income and middle-income countries. Lancet, 2007;370:1929-1938.

24. Edwin AK, Edwin F, Etwire V. Controlling sickle cell disease in Ghana - ethics and options. The Pan African Medical Journal, 2011;10:14

25. Hall V, Thomsen RW, Henriksen O and Lohse N. Diabetes in Sub Saharan Africa 1999-2011: Epidemiology and public health implications. a systematic review. BMC Public Health, 2011. 11:564 doi:10.1186/1471-2458-11564

26. Falkner B, Lurbe E and Schaefer F. High blood pressure in children: clinical and health policy implications. Journal of Clinical Hypertension, 2010;12(4);261-276. DOI: 10.1111/j.1751-7176.2009.00245.x

27. Singh R, Shaw J, and Zimmet P. Epidemiology of childhood type 2 diabetes in the developing world. Pediatric Diabetes, 2004;5:154-168. doi/10.1111/j.1399-543X 28. Agyeman C, Redekop WK, Owusu-Dabo E, Bruijnzeels MA. Blood pressure patterns in rural, semi-urban and urban children in the Ashanti region of Ghana, West Africa. BMC Public Health, 2005; 5(114). doi:10.1186/14712458-5-114

29. Drukteinis JS, Roman MJ, Fabsitz RR . Cardiac and systemic hemodynamic characteristics of hypertension and prehypertension in adolescents and young adults: the Strong Heart Study. Circulation, 2007;115 (2):221-227.

30. Luma GB and Spiotta RT. Hypertension in chil- 
dren and adolescents," American Family Physician, 2006; 73(9):1558-1568

31. Deepa M, Pradeepa R, Anjana RM, Mohan V. Noncommunicable Diseases Risk Factor Surveillance: Experience and Challenge from India. Indian J Community Med, 2011;36(1): PubMed S50-S56.doi: 10.4103/09700218.94709

32. Lurbe E, Cifkova R, Cruickshank JK, Dillon MJ, Ferreira I, Invitti C, Kuznetsova T, Laurent S, Mancia G, Morales-Olivas F, Rascher W, Redon J, Schaefer F,Seeman T, Stergiou G, Wühl E, Zanchetti A; Management of high blood pressure in children and adolescents: recommendations of the European Societyof Hypertension. J Hypertens, 2009;27(9):1719 PubMed -42. doi: 10.1097/ HJH.0b013e32832f4f6b.

33. Atobrah D: When darkness falls at mid-day: Young patients' perceptions and meanings of chronic illness and their implications for medical care. Ghana Medical Journal, 2012; 46(2): 46-53

34. Sackey B. Women and health seeking behaviour in religious contexts: reproductive and ante-natal care in Gha- naian religious movements. A case study of the Twelve Apostles Church. Research Review, 1999; 15 (2): 65-91 35. Twumasi PA. Medical Systems in Ghana. Accra-Tema: Ghana Publishing Corporation. 1975.

36. Vellakkal S, Millett C, Basu S, Khan Z, Aitsi-Selmi A, Stuckler D and Ebrahim S. Are estimates of socioeconomic inequalitiesin chronic disease artefactually narrowed by self-reported measures of prevalence in lowincome and middle-income countries? Findings from the WHO-SAGE survey. J Epidemiol Community Health, 2014. doi:10.1136/jech-2014-204621

37. Vellakkal S, Subramanian SV, Millett C, Basu S, Stuckler D and Ebrahim S. Socioeconomic Inequalities in Non-Communicable Diseases Prevalence in India: Disparities between Self-Reported Diagnoses and Standardized Measures. PLoS One, 2013. DOI: 10.1371/journal. pone. 0068219

38. Mayosi BM, Flisher AJ, Lalloo UG, Sitas F, Tollman SM, Bradshaw D. The burden of non-communicable diseases in South Africa. Lancet, 2009;374: 934-947. doi: 10.1016/S0140-6736(09)61087-4. 